DePauw University

Scholarly and Creative Work from DePauw University

$12-15-2021$

\title{
Spatial Variability in Streambed Microbial Community Structure across Two Watersheds
}

Philips Akinwole

DePauw University, philipsakinwole@depauw.edu

Jinjun Kan

Louis A. Kaplan

Robert H. Findlay

University of Alabama - Tuscaloosa

Follow this and additional works at: https://scholarship.depauw.edu/bio_facpubs

Part of the Microbiology Commons

\section{Recommended Citation}

Philips O. Akinwole, Jinjun Kan, Louis A. Kaplan and Robert H. Findlay. (2021). Spatial variability in streambed microbial community structure across two watersheds. Microbiology Spectrum https://doi.org/10.1128/Spectrum.01972-21

This Article is brought to you for free and open access by the Biology at Scholarly and Creative Work from DePauw University. It has been accepted for inclusion in Biology Faculty publications by an authorized administrator of Scholarly and Creative Work from DePauw University. 


\title{
Spatial Variability in Streambed Microbial Community Structure across Two Watersheds
}

\author{
(D) Philips O. Akinwole, ${ }^{\text {a,c Jinjun Kan, }{ }^{\text {b Louis A. Kaplan, }}{ }^{\text {b }} \text { Robert H. Findlayc }}$ \\ aBiology Department, DePauw University, Greencastle, Indiana, USA \\ bStroud Water Research Center, Avondale, Pennsylvania, USA \\ cDepartment of Biological Sciences, University of Alabama, Tuscaloosa, Alabama, USA
}

ABSTRACT Both spatial and temporal variability are key attributes of sedimentary microbial communities, and while spatial effects on beta-diversity appear to dominate at larger distances, the character of spatial variability at finer scales remains poorly understood, especially for headwater stream communities. We investigated patterns of microbial community structure (MCS) in biofilms attached to streambed sediments from two watersheds across spatial scales spanning $<1 \mathrm{~m}$ within a single stream to several hundred kilometers between watersheds. Analyses of phospholipid fatty acid (PLFA) profiles indicated that the variations in MCS were driven by increases in the relative abundance of microeukaryotic photoautotrophs and their contribution to total microbial biomass. Furthermore, streams within watersheds had similar MCS, underscoring watershed-level controls of microbial communities. Moreover, bacterial community structure assayed as either PCR-denaturing gradient gel electrophoresis (PCR-DGGE) fingerprints or PLFA profiles edited to remove microeukaryotes indicated a distinct watershed-level biogeography. No distinct stream order-level distributions were identified, although DGGE analyses clearly indicated that there was greater variability in community structure among 1st-order streams than among 2nd- and 3rd-order streams. Longitudinal gradients in microbial biomass and structure showed that the greatest variations were associated with 1st-order streams within a watershed, and $68 \%$ of the variation in total microbial biomass was explained by sediment atomic carbon-to-nitrogen ratio (C:N ratio), percent carbon, sediment surface area, and percent water content. This study confirms a distinct microbial biogeography for headwater stream communities driven by environmental heterogeneity across distant watersheds and suggests that eukaryotic photoautotrophs play a key role in structuring bacterial communities on streambed sediments.

IMPORTANCE Microorganisms in streams drive many biogeochemical reactions of global significance, including nutrient cycling and energy flow; yet, the mechanisms responsible for the distribution and composition of streambed microbial communities are not well known. We sampled sediments from multiple streams in two watersheds (Neversink River [New York] and White Clay Creek [WCC; Pennsylvania] watersheds) and measured microbial biomass and total microbial and bacterial community structures using phospholipid and molecular methods. Microbial and bacterial community structures displayed a distinct watershed-level biogeography. The smallest headwater streams within a watershed showed the greatest variation in microbial biomass, and $68 \%$ of that variation was explained by the atomic carbon-to-nitrogen ratio (C:N ratio), percent carbon, sediment surface area, and percent water content. Our study revealed a nonrandom distribution of microbial communities in streambeds, and showed that microeukaryotic photoautotrophs, environmental heterogeneity, and geographical distance influence microbial composition and spatial distribution.

KEYWORDS microbial community structure, microbial biomass, microbial biogeography, microeukaryotes, PLFA, DGGE, watershed

Editor Vincent J. Denef, University of MichiganAnn Arbor

Copyright $\odot 2021$ Akinwole et al. This is an open-access article distributed under the terms of the Creative Commons Attribution 4.0 International license.

Address correspondence to Philips $\mathrm{O}$. Akinwole, philipsakinwole@depauw.edu.

Received 21 October 2021

Accepted 1 November 2021

Published 15 December 2021 
icroorganisms are the most biologically diverse and ubiquitous taxa on Earth, and their metabolic activities largely control biogeochemical cycling and many ecosystem processes (1-3). In stream ecosystems, benthic microbial communities mediate biochemical transformations, including degradation and transformation of organic compounds into biomass or inorganic components, and exert significant control over the mineralization and downstream export of terrestrially derived dissolved organic matter (DOM) (4-8). In addition, microbial processing of terrestrial DOM and nutrients within streambed sediments is essential to material flux to higher trophic levels $(5,9-11)$. However, microorganisms are often ignored or highly aggregated in many stream food web analyses (12).

While the central role of microorganisms in ecosystem functions is well documented, the linkage between microbial community composition and ecosystem functions remains elusive (13), with streams being among the least studied ecosystems. It has been suggested that streams function as meta-ecosystems (14) with a longitudinal acclimation of microbial communities as streams get larger (i.e., increasing stream order) within a drainage network (15). The focus on a longitudinal ecological framework emphasizes central differences among streams and lentic aquatic habitats and underpins two seminal ideas that have guided stream ecosystem research, the River continuum concept (RCC) (16) and nutrient spiraling (17). The RCC emphasizes biodiversity patterns along a longitudinal progression within flowing waters and predicts that biodiversity peaks in mid-sized streams (16). However, the RCC was published before wide-spread use or development of culture-free methods of microbial analysis (18-20) and is notably silent about microorganisms (16), leaving a significant knowledge gap. Also, due to their dendritic nature and spatial and temporal discontinuity (21), stream networks may influence biodiversity patterns beyond just longitudinal constraints. These conceptual differences include association of downstream movement with organisms, energy flow, and nutrient cycling within a physical network where strong directionality and alteration to fluvial geomorphology and hydrology influence energy sources and biogeochemical processes (22). Combined, these characteristics require spatially explicit sampling over a range of scales to better understand how key physicochemical and biological processes impact microbial community composition (22).

The existence of biogeographic patterns that span spatial scales over 7 orders of magnitude has been established for a wide range of microorganisms (23), and, although the mechanisms shaping these patterns have not been identified (24), the drivers of microbial diversity clearly depend upon spatial scale $(25,26)$. The species-area and the distance-decay relationships commonly observed for macroscopic organisms are also common for microbial communities although spore formation or dormant vegetative stages among microbes may contribute to species persistence and reduce the rate of species turnover for microbial communities (27). Relatively few studies have addressed temporal or spatial patterns of heterotrophic microbial community composition in streams, but a clear annual recurrence of taxa within a single stream (28) and a biome-level pattern in microbial community structure for streambed sediments have been observed (29). Alternatively, a study of nine streams across the southeastern and midwestern United States attributed differences in microbial community structure to variations in chemical characteristics of the habitats rather than a pattern driven by spatial gradients (30). Factors contributing to the structure and function of streambed microbial communities include sunlight and water flow (31); water temperature and desiccation (32); hydrology (33-35); $\mathrm{pH}$, sediment grain size, inorganic nutrients, and dissolved oxygen (5); bedrock type (36); interspecific competition, viral lysis, and flagellate grazing (37); anthropogenic pollution $(38,39)$; and DOM concentration and quality $(36,40)$. For instance, the dominant controls over benthic microbial diversity, such as sunlight and algal abundance, contributes to the relative importance of algal- versus terrestrial-derived DOM substrates in lotic systems (41). Changes in light levels have been shown to affect phototrophic growth rates (42). However, the spatial scales at which these local environmental gradients give way to biogeographical processes as the major determinants of microbial community structure and biogeochemical functions have yet to be fully understood (8).

Although over the past decade our understanding of microbial biogeography has continued to expand, there is still a paucity of information on the spatial distribution of 
microbial communities attached to streambed substrata of low-order streams and which factors control geographical patterns at different scales. For instance, slow-changing soil properties, such as total organic carbon across a larger geographical distance, might be a stronger predictor for the microbial community structure than fast-changing soil properties, such as soil moisture of local seasonality (26). Here, we hypothesize that streamed bacteria exhibit spatial variation patterns that are the result of both geographical distance and constraints of environmental selection. Furthermore, hydrologic disturbance and metacommunity dynamics have the potential to determine microbial community structure within watersheds (43), and higher alpha- and beta-diversities have been reported for biofilms growing on rock surfaces in headwater streams than in higher-order streams within a watershed (44). We hypothesize that microbial communities on streambed sediments should exhibit spatially complex, but longitudinally distinct, patterns. More specifically, if the decline in biofilm biodiversity with distance from headwaters observed on rocks in a prealpine watershed (44) were to hold generally for benthic substrata and watersheds, the variability in microbial community structure in biofilms on streambed sediments should decline within a network with downstream distance from the headwaters.

To test these hypotheses, we examined microbial community structure and biomass from streambed sediments in low-order streams within two eastern deciduous forest watersheds of the Delaware River, White Clay Creek, within the Pennsylvania Piedmont and Neversink River (NVR) in the Catskill Mountains of New York. We sampled using a nested design that spanned 5 orders of magnitude across four spatial scales (Fig. 1). We analyzed microbial phospholipid fatty acids (PLFA) to assess total microbial community structure at the resolution of functional groups, performed molecular methods (i.e., PCR-denaturing gradient gel electrophoresis [PCRDGGE]) to assess individual taxa, and used phospholipid phosphate-based analyses to quantify total microbial biomass. Multivariate statistics were used to compare total microbial biomass and microbial and bacterial community structure across distant watersheds.

\section{RESULTS}

Microbial community structure. Across both watersheds, the major component of variation in streambed microbial community structure was the relative contribution of bacteria and microeukaryotes to these communities. We performed a principal-component analysis (PCA) on the fatty acid composition of the streams and found that (i) fatty acids indicative of microeukaryotes (20:4 $\omega 6,18: 2 \omega 6)$, photosystem II (16:1 $\omega 13 \mathrm{t})$, and chrysophytes and chlorophytes $(18: 3 \omega 3,20: 5 \omega 3,16: 3 \omega 4)(45)$ were present in greater relative abundances for streams with more negative principal component 1 (PC1) loadings, and (ii) bacterial fatty acids (cy17:0, cy19:0, a17:0, i17:0, i15:0, br17:1a, and 10me16:0) were present in greater relative abundances for those streams with more positive PC1 loadings (Fig. 2). Within the Neversink River watershed, the contribution of microeukaryotes ranged from $42 \%$ (NVR) to 12\% (Pigeon Creek Tributary B [PBB]), and in the White Clay Creek watershed, the range was 31\% (Walton Spring Brook [WSB]) to 4\% (Dirty Dog Spring [DDS]) (see Table S1 in the supplemental material). The percentage that microeukaryotes comprise of total microbial biomass and PC1 factor scores showed a strong, negative correlation $\left(r^{2}=0.88\right)$ (Fig. 3a). Thus, the position of stream communities along PC1 were arrayed according to the proportions of prokaryotes and microeukaryotes within communities, moving from negative to positive PC1 loadings as the relative contribution of microeukaryotes decreased. PC1 separated the two streams that showed the highest relative contribution of microeukaryotes (NVR and WSB) from all other streams (Fig. 2). To further investigate the role of microeukaryotic community structure on this relationship, percent contribution of microeukaryotes to total biomass was compared to the ratio of fatty acid markers for phototrophs $(\omega 3)$ to fatty acid markers for heterotrophs $(\omega 6)$. The strong positive linear correlation between these two parameters indicated that increasing importance of microeukaryotes within the microbial community correlated with increasing importance of phototrophs within the microeukaryotic community $\left(r^{2}=0.71\right)$ (Fig. 3b). Furthermore, in Fig. 2, the streams (except NVR) were separated at the scale of watershed along principal component 2 (PC2), as White Clay Creek (WCC) streams had positive PC2 scores while the Neversink streams had negative 
a
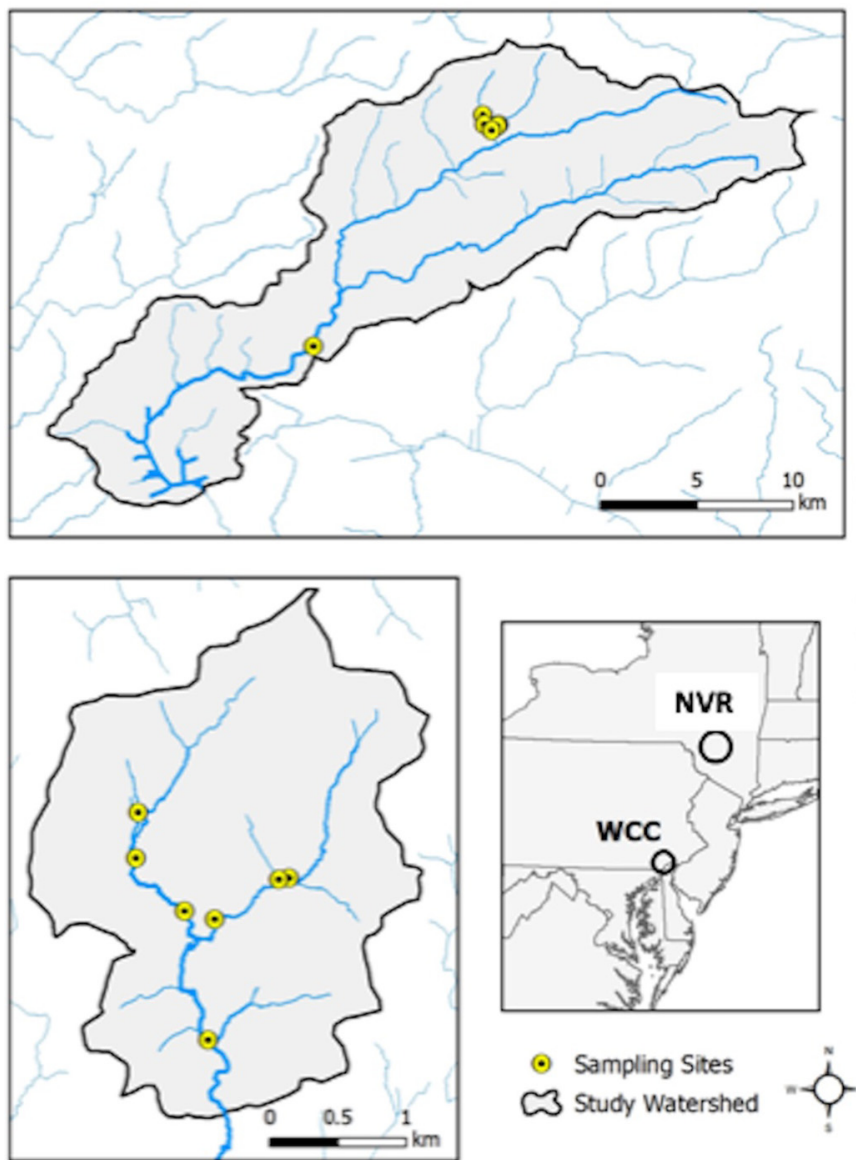

b

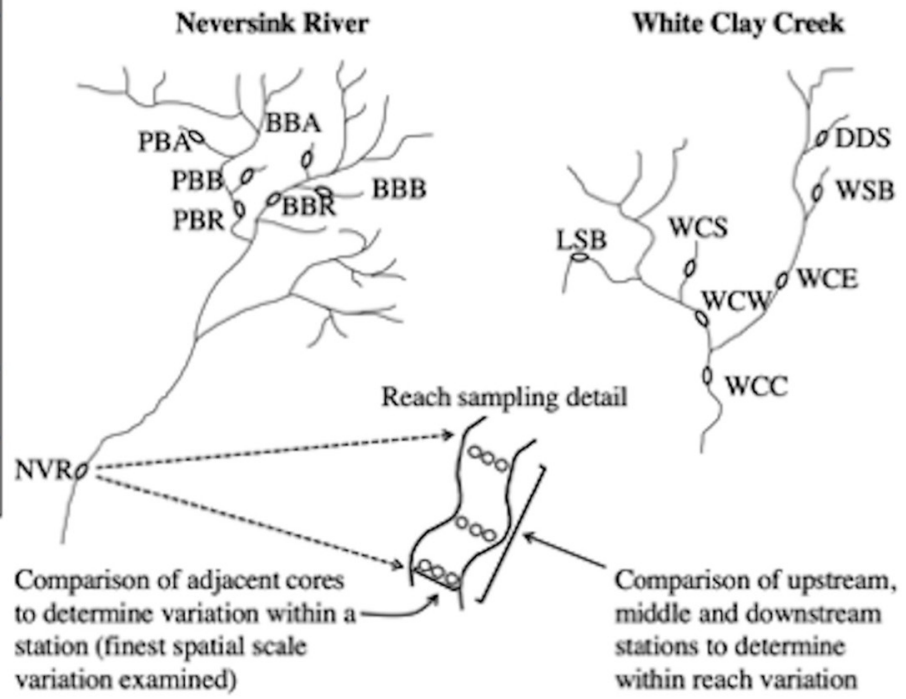

FIG 1 (a) Map of the Neversink watershed in New York and White Clay Creek watershed in Pennsylvania, USA. (b) Sampling scheme used to examine microbial biomass and community structure across multiple spatial scales in the two watersheds. Sampling within the Neversink watershed consists of four 1st-order streams, Biscuit Brook and Pigeon Creek tributaries (Biscuit Brook Tributary A and B [BBA, BBB] and Pigeon Creek Tributary A and B [PBA, PBB]), two 3rdorder streams (Biscuit Brook [BBR] and Pigeon Creek [PBR]), and one 5th-order stream (Neversink River [NVR]). Sampling within the White Clay Creek watershed consists of four 1st-order streams (Ledyards Spring Branch [LSB], Water Cress Spring [WCS], Dirty Dog Spring [DDS], and Walton Spring Branch [WSB]), two 2nd-order streams (East and West Branch White Clay Creek [WCE, WCW, respectively]), and one 3rd-order stream (White Clay Creek [WCC]). Sketches of watersheds are not drawn to scale. Each eclipse represents a reach, which contained 3 stations, each of which was sampled 3 times.

PC2 scores. Within a watershed, microbial community composition of streambed sediments from 1st-, 2nd-, and 3rd-order streams were, in general, similar. Within the Neversink watershed, all the streambed sediments from the lower-order streams formed a cluster separate from the 5th-order NVR, while only the 1st-order stream with an open canopy in the White Clay Creek watershed, WSB, separated from the cluster of other streams (Fig. 2).

No consistent longitudinal variations among stations within a stream were observed for microbial community composition (Fig. S1); that is, there were no consistent differences among cores from the upper, middle, and lower station of a reach. Rather, for some stations, the three replicate cores showed nearly identical microbial community structure (Fig. S1a and $b$, dashed circle), while for other stations, the three replicate cores differed greatly in microbial community structure (Fig. S1a and b, dotted ellipse). In addition, cores from different stations within a stream (Fig. S1, horizontal arrows) and, in a few cases, cores from different streams within a watershed (Fig. S1, vertical arrows) showed nearly identical microbial community structure.

Bacterial community structure. When bacteria alone are considered, community structure of streambed sediments separated out by watershed for both the lipid and molecular approaches to assess community structure; all streams in the Neversink River watershed had negative factor scores, and all streams within the White Clay Creek watershed had positive factor scores (Fig. $4 a$ and b). At the spatial scale of streams within a watershed, no clear 


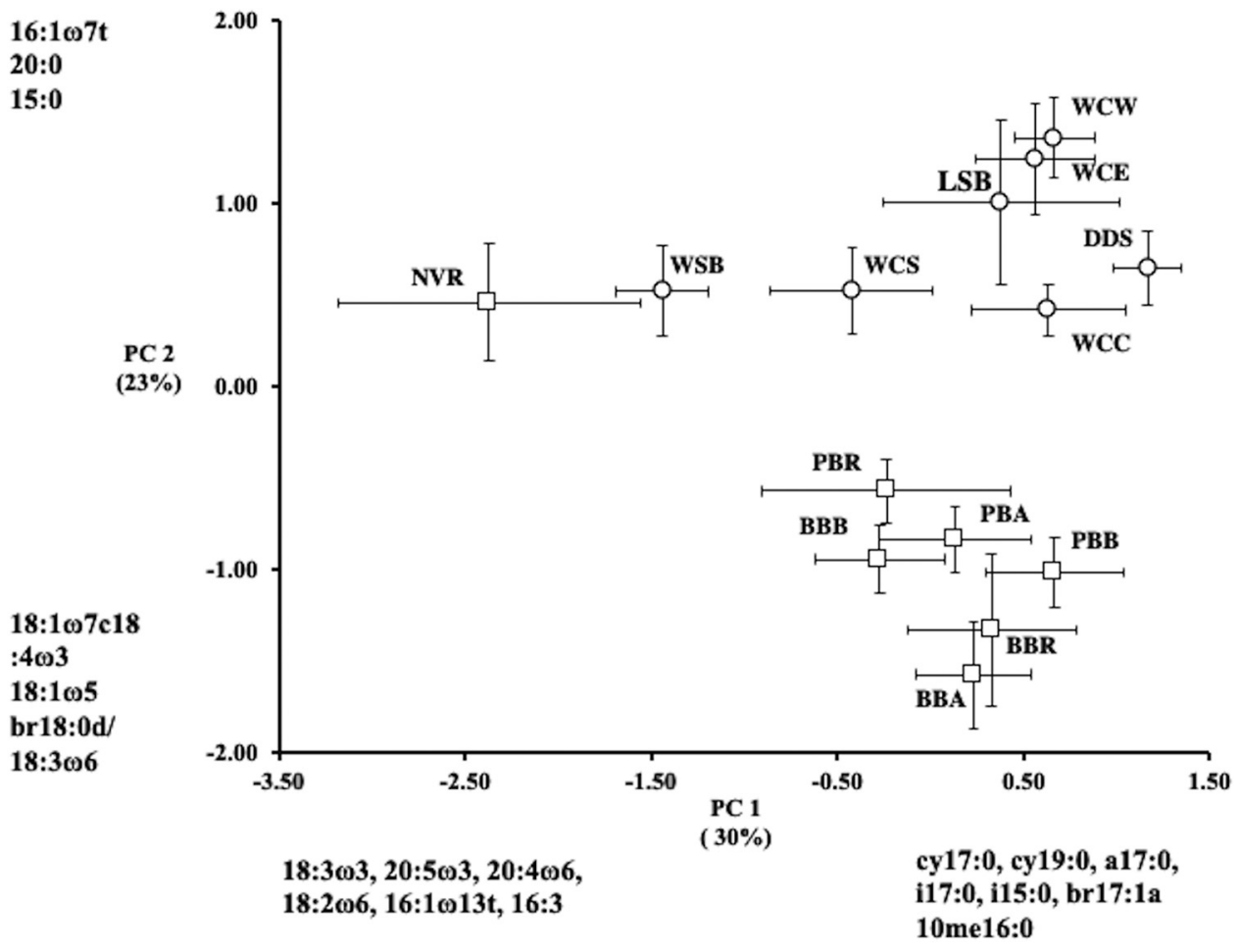

FIG 2 Principle-component analysis of stream sedimentary microbial community structure of PLFA profiles of White Clay Creek (open circle) and Neversink (open square) watersheds. The percent variation explained by each axis is indicated on the respective component axis. Identified fatty acids had component loadings of $>|0.5|$ with strong influence on the pattern of variation among samples along the respective component axes. Site abbreviations are as described in the legend to Fig. 1.

longitudinal separation of stream orders was observed, although the variation in bacterial community structure among 1st-order streams assayed by DGGE was greater than that observed for 2 nd- and 3rd-order streams (Fig. 4b, fine versus coarse dashed boxes). At the spatial scale of replicate cores within a station $(<1 \mathrm{~m})$, bacterial community structure assayed by PLFA showed patterns similar to those observed for microbial community structure (Fig. S1a and b).

Total microbial biomass. Streams from the WCC watershed showed greater ranges and higher basin-wide averages for total microbial biomass concentration $(29.73 \pm 18.23 \mathrm{nmol}$ $\mathrm{g}^{-1}$ fresh wet weight $\left.[\mathrm{fww}]\right)$, percent prokaryotic content $(88 \% \pm 9.71)$, and bacterial abundance $\left(9.85 \times 10^{8} \pm 4.75 \times 10^{8} \mathrm{~g}^{-1} \mathrm{fww}\right)$ than streams within the Neversink River watershed, $\left(10.87 \pm 6.53 \mathrm{nmol} \mathrm{g}^{-1} \mathrm{fww}, 77.5 \% \pm 11.40\right.$, and $3.30 \times 10^{8} \pm 1.24 \times 10^{8} \mathrm{~g}^{-1} \mathrm{fww}$, respectively) (Table S1; Fig. S2). The microbial biomass differences were significant at the levels of watersheds $(F=15.18, P \leq 0.005)$ and streams within watersheds $(F=7.38, P \leq 0.001)$ but not stations within streams (Table 1; Fig. S2). At the scale of stations within streams (1 to $50 \mathrm{~m}$ ), variability in sediment microbial biomass, expressed as a coefficient of variation, ranged from $30 \%$ to $79 \%$ with no consistent longitudinal pattern of biomass changes among stations (Fig. $\mathrm{S} 2 \mathrm{~b})$. The coefficient of variation for microbial biomass among replicate cores within stations ranged from $5 \%$ to $83 \%$ (Fig. S2c).

Water chemistry and sediment organic content. Differences between the two watersheds in bedrock geology and glaciation history were clearly reflected in stream water conductivity, which was $\sim 5$-fold greater in WCC watershed streams than in the Neversink watershed streams (Table S1). Sediment carbon (C) and nitrogen (N) content in streams from the watersheds had overlapping ranges, but, on average, sediments from the WCC watershed had 3.5-fold higher percent $\mathrm{C}$ and 3-fold higher percent $\mathrm{N}$ than the sediments from the Neversink watershed, and the atomic carbon-to-nitrogen ratio (C:N ratio) was 1.5fold higher in the WCC watershed (Table S1; Fig. 5). Streams from the White Clay Creek West (WCW) subbasin containing patches of carbonate bedrock had the highest conductivity 

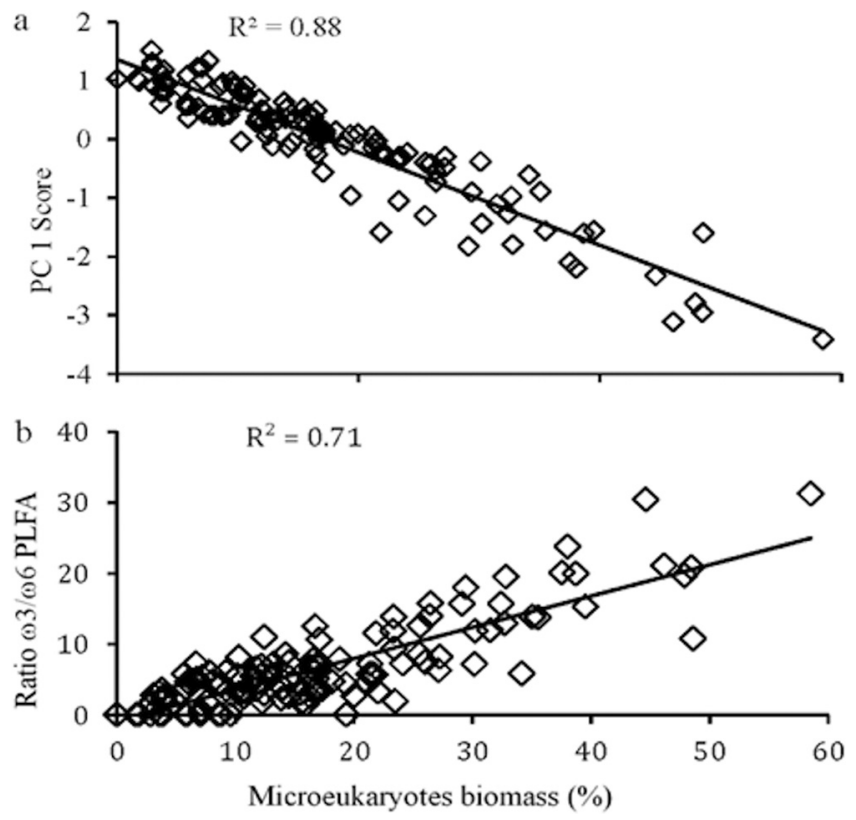

FIG 3 (a) Relationship between principle-component analysis factor 1 score and the calculated percentage that microeukaryotes contribute to total microbial biomass for all stream samples. (b) Relationship between the calculated percentage that microeukaryotes contribute to total microbial biomass and the ratio of $\omega 3$ to $\omega 6$ fatty acids for all stream samples from the PLFA profiles.

within the WCC watershed and consistently greater $C$ and N content than other streams in that watershed, although the high variation within cores for each stream impacted the number of significant differences among all streams, especially for $\mathrm{N}$ content (Fig. 5a and b). In general, sediment C:N mass ratios were higher in 1st- and 2nd-order streams and lower in 3rd- and 5th-order stream sediments (Fig. 5c). Combined, sediment percent carbon content, percent water content, C:N mass ratio, and sediment surface area explained approximately two-thirds of the variation observed in sedimentary microbial biomass (Table 2, model 7). Path analysis indicated that the variables percent carbon content, percent water content, and C:N ratio had significant direct effects on biomass and that sediment surface area was positively and significantly correlated with those three variables (Fig. 6). Two models were investigated to discern the theoretical linkage and directionality among the variables, one constrained and one unconstrained. The constrained model links sediment surface area indirectly to biomass via its direct effects on sediment carbon and water content, while the unconstrained model links surface area indirectly to biomass via its correlations with sediment carbon content, water content, and C:N ratio. These two models yielded very similar results, and we present only the unconstrained model. Percent carbon content showed the greatest direct effect on biomass $\left(r^{2}=0.393\right)$ as well as substantial indirect effects via its correlation with percent water content and C:N mass ratio (Fig. 6). Combined, the direct and indirect effects of carbon accounted for $\sim 61 \%$ of the variation in total sediment microbial biomass. Similarly, percent water content and C:N mass ratio accounted for $56 \%$ and $37 \%$, respectively, of the variation in total sediment microbial biomass. Sediment surface area via indirect effects accounted for $\sim 34 \%$ of the variation in total sediment microbial biomass (Fig. 6).

\section{DISCUSSION}

Spatial variability of microbial community structure and the role of phototrophic microeukaryotes. Our results indicate that microbial community structure in the 14 headwater streams investigated within the Eastern Deciduous Forest biome displayed a distinct regional-level spatial variability, even when streams within a watershed displayed high within-stream or among-stream variations. Sediments from the WCC and Neversink River watersheds, with the exception of sediments from the 5th-order Neversink River site, differed in total microbial community structure; this difference was detected by the second 

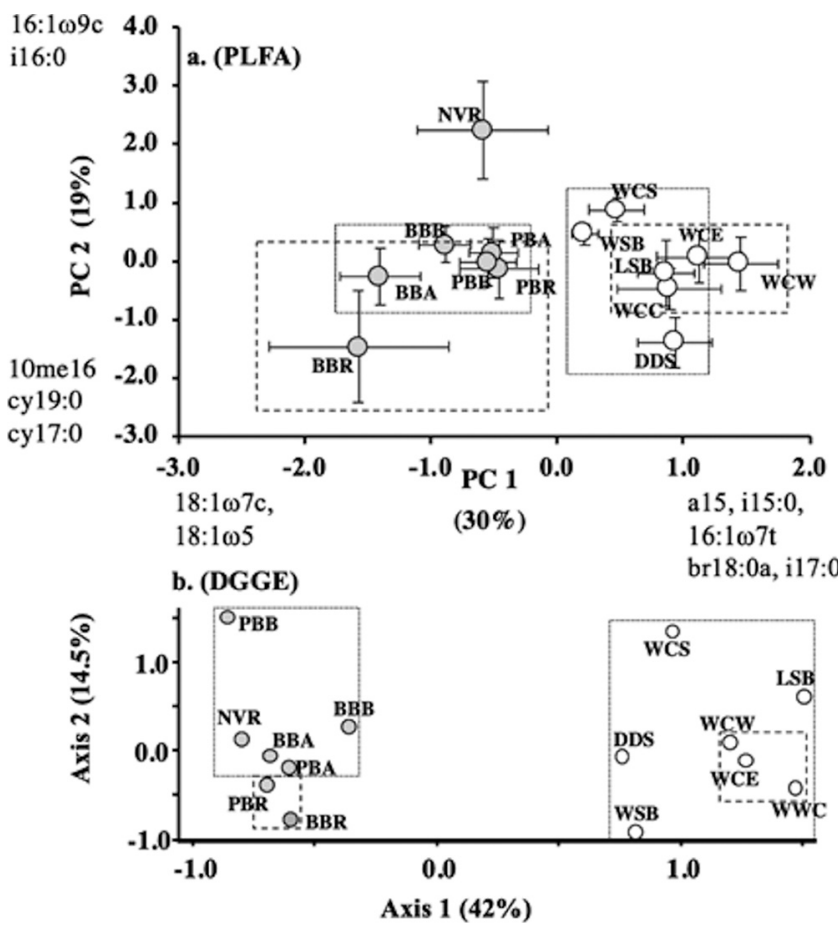

FIG 4 Sedimentary bacterial community composition in WCC and NVR watersheds. (a) PCA analysis of PLFA profiles after removal of fatty acids assigned a priori to the functional group microeukaryotes and those known to be common to both bacteria and microeukaryotes from the PLFA profiles. (b) NMDS analysis of DGGE presence/absence data. Streams within the White Clay Creek dendritic network are denoted with open circles, and those within the Neversink dendritic network are denoted with filled circles. Site abbreviations are as described in the legend to Fig. 1. Dotted boxes indicate the relative variation in bacterial community structure of 1st-order stream sediments within a watershed, and dashed boxes indicate the same for the 2nd- and 3rd-order streams or 3rd-order streams within the watershed.

component of variation. These findings extend previous studies that indicate that geographical distance is important in structuring microbial communities at regional scales $(26,28,29)$ and provide further evidence for spatial variations in microbial community structure (27). For instance, in a recent study, Zhang et al. (26) investigated soil microbial communities along a ca. 878-km transect during two contrasting seasons and reported that spatial heterogeneity rather than seasonality explained more of the spatiotemporal variation of soil microbial alpha- and beta-diversities. In a Findlay et al. study (29), when sediment microbial community structure was compared among three biomes, microbial communities within a biome were more similar in composition than communities from different biomes that differed in environmental heterogeneity. A major difference between our study and that of Findlay et al. (29) was that the two watersheds examined in this study occurred within the same Eastern Deciduous Forest biome with some overlap in the dominant tree species but with other notable differences. Only the Neversink watershed was glaciated during the last glacial period and that generated differences in soil age and structure and bedrock geology, and the WCC watershed has more agricultural land use. These differences led us to expect different microbial community compositions between the watershed

TABLE 1 Nested analysis of variance to test the effects of watershed, streams within a watershed, and stations within streams on microbial biomass

\begin{tabular}{llllll}
\hline Source & DF $^{a}$ & Adj SS $^{a}$ & Adj MS $^{a}$ & $F$ & $P$ \\
\hline Watershed & 1 & 5.119 & 5.119 & 15.18 & 0.002 \\
Stream (watershed) & 12 & 4.047 & 0.337 & 7.38 & 0.000 \\
Stations (watershed*stream) & 28 & 1.280 & 0.046 & 1.46 & 0.095 \\
Error & 84 & 2.628 & 0.031 & & \\
\hline
\end{tabular}

${ }^{a} \mathrm{DF}$, degrees of freedom; adj SS, adjusted sum of squares; adj MS, adjusted mean square. 

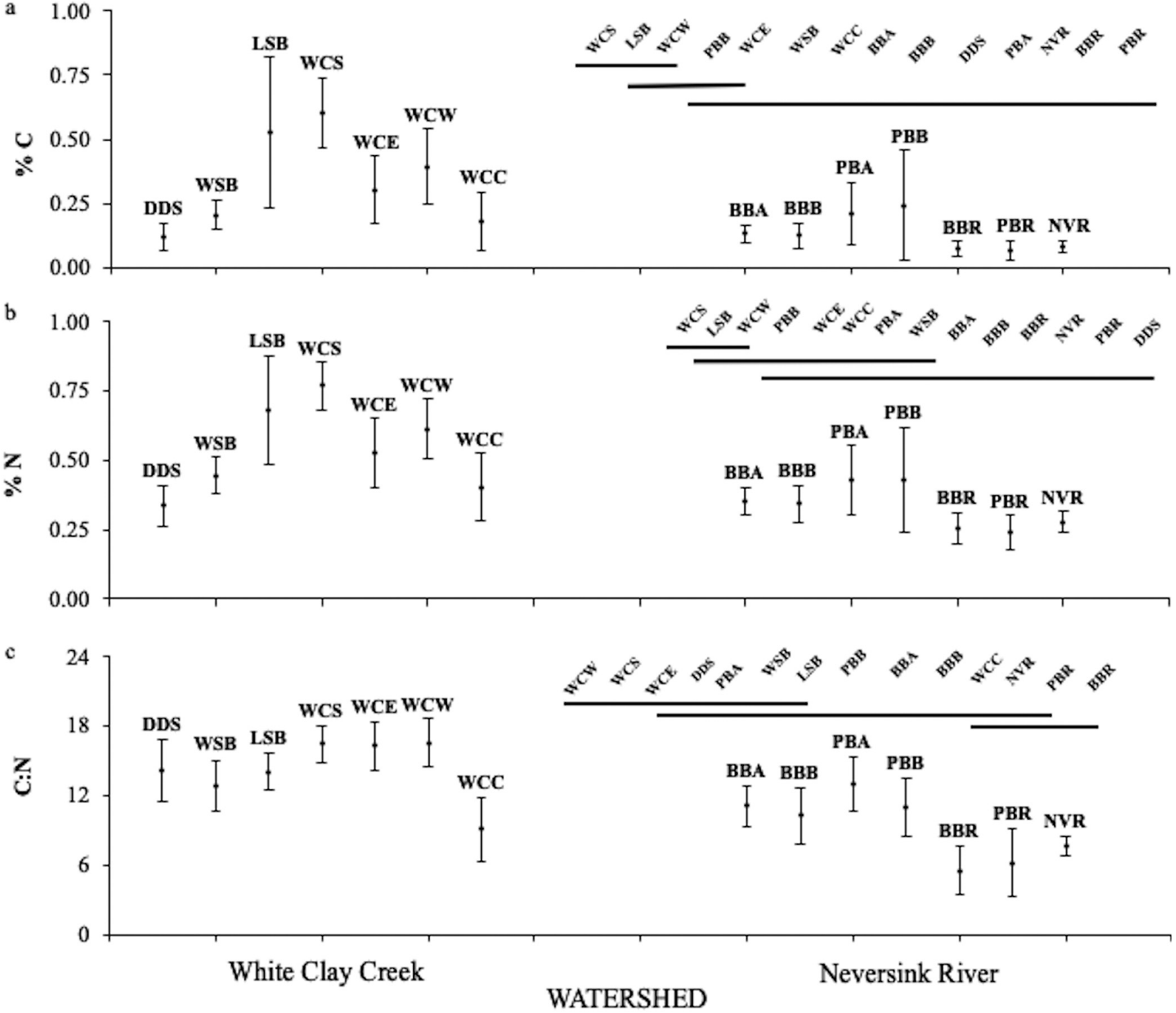

FIG 5 Variation in sediment percent carbon (a), percent nitrogen (b), and C:N mass ratio (c) by stream order (1st to 3rd/5th order from left to right) and watershed. Vertical bars denote 0.95 confidence intervals. Streams not connected by a horizontal line are significantly different $(P=0.05$, Tukey's wholly significant difference).

that would be detected at the regional scale. In this study, we showed that the WCC and Neversink watersheds differed in C:N mass ratio, percent carbon, sediment surface area, and microeukaryotic/prokaryotic ratio, suggesting that these factors, along with others, affect spatial variability of freshwater sediment microbial communities at a variety of scales within watersheds.

One major component of variation in microbial community structure reflects the ratio of microeukaryotic to prokaryotic biomass. As streams with high microeukaryotic biomass were dominated by phototrophs, and light has long been known as a major factor influencing the relative abundance of microeukaryotes within microbial communities $(41,46)$, canopy cover likely influenced the placement of streams along this gradient. While canopy cover was not directly measured, the $>20$-m-wide 5th-order NVR station is largely clear of riparian tree shade, and abundant, dense filamentous algal streamers were observed attached to cobble on the streambed. The shift in community structure at the NVR site is consistent with predictions of the RCC of shifts from a heterotrophic regimen to more autotrophic production with an expanded role for periphyton as the canopy opens in mid-order streams (16). 
TABLE 2 Multiple regression analysis (best subsets) for natural log biomass as a function of various physical and chemical stream parameters

\begin{tabular}{llllllllll}
\hline Model & Vars $^{a}$ & $R^{2}(\mathrm{adj})$ & Mallows $^{a} \mathrm{p}^{b}$ & $\mathrm{SE}^{a}$ & \%Water $^{a}$ & $\mathrm{SSA}$ & $\% \mathrm{C}$ & $\% \mathrm{~N}$ & $\mathrm{C}: \mathrm{N}$ \\
\hline 1 & 1 & 60.4 & 30.2 & 0.2052 & & & $\mathrm{X}$ & & \\
2 & 1 & 56.0 & 46.3 & 0.2161 & $\mathrm{X}$ & & & & \\
3 & 2 & 64.4 & 15.9 & 0.1943 & & & $\mathrm{X}$ & & $\mathrm{X}$ \\
4 & 2 & 64.0 & 17.6 & 0.1955 & & & $\mathrm{X}$ & $\mathrm{X}$ & \\
5 & 3 & 66.7 & 8.4 & 0.1879 & & $\mathrm{X}$ & $\mathrm{X}$ & & $\mathrm{X}$ \\
6 & 3 & 66.0 & 11.1 & 0.1899 & $\mathrm{X}$ & & $\mathrm{X}$ & & $\mathrm{X}$ \\
7 & 4 & 68.1 & 4.3 & 0.1839 & $\mathrm{X}$ & $\mathrm{X}$ & $\mathrm{X}$ & & $\mathrm{X}$ \\
8 & 4 & 67.0 & 8.5 & 0.1872 & $\mathrm{X}$ & $\mathrm{X}$ & $\mathrm{X}$ & $\mathrm{X}$ & \\
9 & 5 & 68.0 & 6.0 & 0.1845 & $\mathrm{X}$ & $\mathrm{X}$ & $\mathrm{X}$ & $\mathrm{X}$ & $\mathrm{X}$ \\
\hline
\end{tabular}

aVars, variables; adj, adjusted; SE, standard error; $X$, explanatory variable(s) in the model; SSA, sum of squares among groups.

${ }^{b}$ The model giving the minimum Mallows $C p$ statistic was used (80).

cModel 7 showing the variables that contributed the most to the variation in microbial biomass.

One of our 1st-order streams, WSB, arises from soils with a high-water table, making the trees subject to windthrow, creating an opening in the forest canopy. The theoretical role of an open canopy in shifting community composition to more phototrophy as predicted by RCC was seen in WSB in the headwaters of the WCC watershed rather than downstream. This phenomenon is consistent with the mechanism behind the RCC prediction but a special case associated with the height of the water table, indicating that a substantial part of network-wide biodiversity may rest in the large environmental variation among headwater.

In this study, microeukaryotes contributed from 4.0 to $40.9 \%$ of microbial biomass, and at the lower portion of the range (10\% or less), PLFA profiles indicated that heterotrophs were the dominant microeukaryotes, while in communities with larger proportions of microeukaryotes, phototrophs were dominant. This was evidenced by the shift in the ratio of $\omega 3$ to $\omega 6$ PLFAs. While $\omega 3$ and $\omega 6$ fatty acids are found in both heterotrophic and phototrophic microeukaryotes, they differ in their relative abundance (45-47). In heterotrophic eukaryotes, the abundance of $\omega 6$ and $\omega 3$ fatty acids are comparable, while in phototrophic

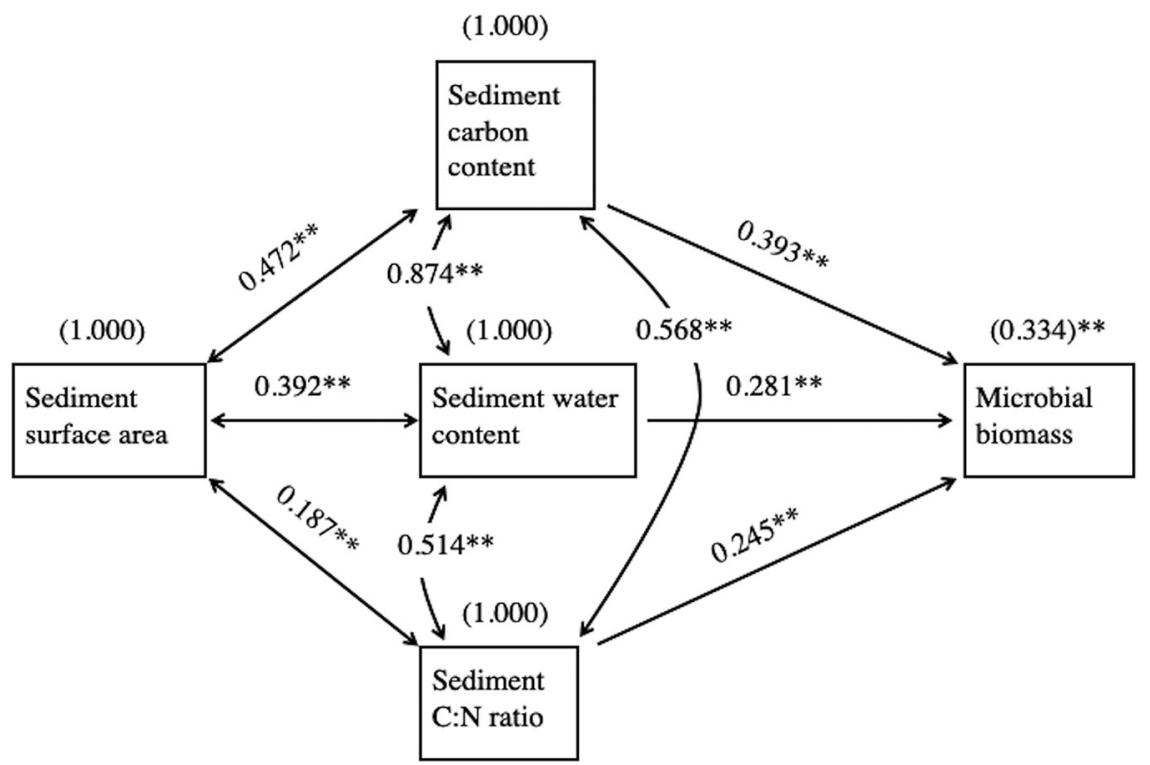

FIG 6 Path diagrams describing the structure of the relationship between sediment microbial biomass and percent carbon $(\% \mathrm{C})$, percent water content, $\mathrm{C}: \mathrm{N}$ mass ratios $(\mathrm{C}: \mathrm{N})$, and sediment surface area (SSA). Single-headed arrows indicate casual paths; numbers on arrows are path coefficients (standardized regression coefficients) indicating the relative strength of each path leading to a given response variable. Double-headed arrows represent the correlations among the predictor variables. Arrows connecting environmental variables to the independent variable (microbial biomass) indicate direct effects, while environmental variables linked to the independent variable via other environmental variables constitute indirect effects. Path coefficients were calculated by SAS; structural equation modeling for JMP $10 ;{ }^{*}, P<0.01 ;{ }^{* *}, P<0.001$. 
eukaryotes, $\omega 6$ fatty acids typically constitute $\sim 10 \%$ of the $\omega 3$ fatty acid abundances. Across the streams in this study, the relative concentrations of $\omega 6$ and $\omega 3$ fatty acids are consistent with phototrophic microeukaryotes comprising upwards of $75 \%$ of the microeukaryotic community of sediments with high percent microeukaryotes. The contribution of heterotrophic microeukaryotes to total microbial biomass in streambed sediments is likely limited by trophic interactions, unless seasonal and hydrodynamic conditions allow accumulation of significant leaf litter colonized by fungi, while the contribution of phototrophic microeukaryotes is likely limited by light availability and to a lesser extent biotic and abiotic disturbance and nutrient availability (48-50). Thus, it is clear that the presence of phototrophic microeukaryotes alters microbial community structure and function.

Our study showed that a critical, and often overlooked, factor in the microbial ecology of streambed sediments is the ability of open canopy/light, as seen in the NVR and WSB stations, to shift the ratio of microeukaryotic to prokaryotic biomass and the nature of the reflected interactions. This is evidenced by the findings that the major component of variation in sediment microbial community structure is driven by microeukaryotic/prokaryotic ratio, as shown in this study (Fig. 3$)$ and others $(29,44)$. For watersheds where shading of streams occurs, we posit that the ratio of microeukaryotic to prokaryotic biomass is an essential component of any study striving to understand the critical roles that sediment microorganisms play in the ecology and biogeochemistry of fluvial networks.

Bacterial community structure. In this study, PLFA and DGGE analysis yielded similar patterns of distinct watershed differences in bacterial community structure (Fig. 4a and b). The variation in bacterial community structure at regional scales may involve multiple causal pathways resulting from a complex relationship between geology, bacterial community structure, and DOM quality. For instance, differences in watershed characteristics, including bedrock geology and water chemistry, generate differences in DOM qualities and quantities $(40,51)$, which in turn cause variation in stream sediment bacterial community structure (36). The complexity arises in that streambed microorganisms can, in turn, affect DOM quantity and quality (52). Wagner et al. (53) demonstrated clear shifts in bacterial community structure that included direct effects (increased relative abundance of cyanobacteria and other phototrophic bacterial taxa) as well as apparent indirect effects, such as the increased relative abundance of predominately heterotrophic taxa, such as Roseomonas and Rivibacter, along with decreases in others, such as Planctomycetes and Gemmatimonadetes. They also demonstrated, along with Rier et al. (54), a strong positive correlation among enzyme activities associated with heterotrophic bacteria and increasing light levels, and in the Rier et al. (54) study, these increases were greater than the increase in bacterial biomass.

Land use may be an alternative proximate cause for the observed variation in bacterial community structure between the two watersheds. The Neversink watershed is $95 \%$ forested while the WCC watershed, with its mixture of cropland, pasture, and forest, has a long history of agricultural land use, which is known to strongly affect sediment microbial communities (55). In addition, our data indicated significant differences in conductivity and sediment C:N mass ratios between the two watersheds, either of which can also significantly affect bacterial community structure. Microbial biogeography studies show that for geographic distance relevant to our study, deterministic processes primarily govern bacterial communities, and their structure reflects local environmental heterogeneity, although distance effects are also noted $(23-26,56,57)$. In this study, microbial community structure was influenced by light, and total microbial biomass was strongly influenced by sediment carbon content, water content, C:N mass ratio, and surface area (see below). It is reasonable to assume that these factors may also influence bacterial community structure. As a quick fingerprinting approach, PCR-DGGE primarily focuses on the most abundant populations within a community $(58,59)$. The minor groups where the most microbial diversity exists are undetected and escape from our analysis in this study. Therefore, PCR-DGGE provides a quick "snapshot" of population dynamics across spatial scales, and, compared to the detailed microbial characterization via high-throughput sequencing, it underestimates the alpha- and beta-diversity for the streambed samples. However, a reexamination of "old" preserved DNA with next-generation sequencing (NGS) demonstrated that DGGE catches 
the major picture of population spatiotemporal dynamics $(60,61)$. Therefore, we feel confident that the DGGE analysis in this study along with PLFA fingerprinting were able to provide valuable information on community composition, albeit with lower taxonomic resolution.

Besemer et al. (44) found greater alpha and beta bacterial diversity among epilithic headwater stream communities than in larger streams of the same network. Although neither of the fingerprinting assays used in this study produced direct measures of diversity and the Besemer study (44) used biofilms removed from rock surfaces, our experimental design provides several tests of their hypothesis that headwater streams are a reservoir of bacterial diversity. These include a comparison of the variation in community structure found in the four 1st-order streams in the WCC watershed versus the 2nd- and 3rd-order WCC streams and a comparison of the four 1st-order Pigeon and Biscuit Brook tributaries to the 3rd-order Pigeon and Biscuit Brooks. In three of these comparisons, sediments from the headwater streams showed substantially greater variation in bacterial community structure than sediments from the corresponding downstream stations, while by one comparison (PLFA, Neversink streams), variation in bacterial community structure was greater among the downstream stations than among the headwater streams (Fig. 4a). These findings suggest that the observed pattern of highest bacterial diversity in epilithic stream biofilms within the smallest headwater streams likely extends to surficial streambed sediments. This contrasts with the prediction of the RCC that highest biotic diversity would occur in midorder streams, but the RCC predictions were based on observations associated with higher organisms and preceding major advances in microbial ecology (44). As dendritic ecological networks, fluvial systems experience a broad suite of coupled physical, chemical, and biological processes that strongly influence microbial community structure (62). In the Eastern Deciduous biome, headwater streams are typically shaded and net heterotrophic, receiving appreciable inputs of terrestrial organic matter. Hierarchical patch dynamics within the local terrestrial environment, also resulting from a broad suite of coupled physical, chemical, and biological processes, provide varied terrestrial contributions to stream water DOM, which in turn exerts significant influence on bacterial community structure $(36,40,44)$. While our study does not allow for direct measurement of alpha- or beta-diversity, the sampling density used for PLFA analysis does address aspects of a critical question within microbial ecology, that is, the spatial scales of patch size for streambed sediments. Given the dimensions of our streambed sediment sampling rings, our results indicate that in these headwater streams, there is a spatial scale of variation on the order of $\leq 10 \mathrm{~cm}$. In addition, each reach contains multiple patches, a given patch (defined by microbial community structure, as in reference 63) can occur at multiple spatial sizes and boundaries within a stream and in multiple streams within the watershed (Fig. S1 in the supplemental material). Using PC1 scores, we calculated that the adjacent triplicate cores taken within a station encompassed anywhere from $10 \%$ to $100 \%$ of the variation observed for that stream. While this study did not directly investigate the impact of local heterogeneity on streambed microbial community structure, the factors explaining variation in total microbial biomass likely contribute to variation observed in community structure.

Microbial biomass and environmental variables. At spatial scales of the watershed and stream, total microbial biomass showed significant differences but did not show a consistent trend within stations or triplet cores. Multiple regression analysis indicated that percent sediment carbon content, percent water content, C:N mass ratio, and sediment surface area explained nearly $70 \%$ of the variance in sediment biomass. Path analysis indicated that primary direct control was via sediment organic carbon, C:N ratios, and sediment water content, while sediment surface area affected sediment biomass indirectly via its impact on the other three variables. All four are known to be important environmental constraints of streambed microbial biomass, and sediment organic carbon reflects a combination of several biogeochemical processes $(64,65)$ that influence microbial biomass through its quantity, quality, or a combination thereof. Previous studies of stream sediments and terrestrial soils have shown the quantity of carbon significantly influenced microbial biomass (66-69). The results from this study further corroborate those observations and show that increasing sediment 
organic carbon concentration leads to greater total microbial biomass both directly and indirectly via interactions with C:N mass ratio and sediment water content (Fig. 6).

In addition, Findlay et al. (70) showed that variation in quality of sediment detritus, as measured by $\mathrm{C}: \mathrm{N}$ mass ratio, was negatively correlated with bacterial abundance, while Schallenberg and Kalff (66) found either negative correlations or no correlation in lake sediments. Our results that total microbial biomass correlated positively with both sediment organic carbon and C:N mass ratio suggest that organic carbon quantity can supersede the effects of quality, although increasing sediment $C$ concentration combined with increasing $\mathrm{C}: \mathrm{N}$ ratio might indicate an increased presence of fine particulate organic matter, which is known to be positively correlated with microbial biomass (71, 72). The cause of the difference between our findings and those of previous researchers is not known; however, the Findlay et al. (70) study did focus on particulate organic carbon, while in this study, total sediment carbon was measured, and the range of $\mathrm{C}: \mathrm{N}$ mass ratios did differ in the two studies (9 to 27 versus 6 to 17; reference 70 versus this study, respectively).

Schallenberg and Kalff (66) working with lake sediments that ranged from $46 \%$ to 99\% water content found that percent water content was the single most important variable in predicting sediment bacterial biomass. In this study, sediments exhibited a wide range of sediment water content and required the recommended normalization to fresh weight (66). This is reflected in our finding that percent water content was the second most important variable in predicting sediment microbial biomass. High percent water content allows for greater aqueous connectivity within sediment, which in turn allows nutrient and substrate transfer, providing microorganisms with a continuous supply of nutrients as well as means to move to more favorable locations $(73,74)$. Nogaro et al. (75) working with sediment porosity (sediment water content corrected for adsorbed water) extended its importance to a deterministic process governing riverbed bacterial community.

Finally, sediment surface area has long been known to impact microbial communities, although many early studies (before the popularization of the Brunauer-EmmettTeller method [76]) report this parameter in terms of sediment grain size $(77,78)$. Surface area of streambed sediments can influence microbial biomass through its effects on flow rates and availability of nutrients $(79,80)$ and quantity and quality of organic carbon $(81,82)$. In this study, path analysis indicated that the effect of sediment surface area on microbial biomass was indirect via its direct effects on sediment C:N mass ratio and carbon and water content.

\section{CONCLUSION}

Our study revealed regional-level patterns in microeukaryotes and bacterial community structures and adds to the growing number of studies suggesting that regional-scale environmental factors influence the biogeography of microbes. At the same time, we observed that local environmental factors strongly influence sediment microbial biomass, which can vary greatly among streams within a watershed, particularly among its 1st-order streams. Our findings highlight that variations in microbial community structures within streams reflect a mosaic of small-scale patches and suggest that the type and spatial arrangement of patches is an important and often overlooked component of studies of metacommunity ecology of fluvial networks. Lastly, the fact that bacteria in headwater streams are typically components of a mixed-phylum community (83) and a growing literature that documents the impacts of microeukaryotes on microbial community structure underscore a need to place research on bacterial community structure based on molecular methods into a broader phylogenetic context (84).

\section{MATERIALS AND METHODS}

Study sites. Study streams were located within the $1 \mathrm{st}$ - to 3rd-order, $7.3-\mathrm{km}^{2}$ East Branch White Clay Creek (WCC) within the southern Pennsylvania Piedmont $\left(39^{\circ} 53^{\prime} \mathrm{N}, 75^{\circ} 47^{\prime} \mathrm{W}\right)$ and the 1 st- to 5th-order, $171-\mathrm{km}^{2}$ Neversink River in the Catskill Mountains of New York $\left(41^{\circ} 57^{\prime} \mathrm{N}, 85^{\circ} 29^{\prime} \mathrm{W}\right)$ (Fig. 1). Predominant land uses within the WCC watershed upslope of an intact forested riparian zone are row crop agriculture (52\%), hayed/grazed fields $(22 \%)$, and wooded lands $(23 \%)(85,86)$ arrayed across elevations ranging from $100 \mathrm{~m}$ to $146 \mathrm{~m}$. At the 3rd-order site, mean annual streamflow, stream water temperature, and local precipitation are $115 \mathrm{~L} / \mathrm{s}, 10.6^{\circ} \mathrm{C}$, and $105 \mathrm{~cm}$, respectively (85). Soils are deep, unglaciated Utisols, and streambed sediments 
consist of clay-, silt-, and sand-sized particles in pools and runs, with gneiss- and schist-derived gravel and cobble throughout all of the riffles; riffles from the western tributary and main stem of WCC also contain metamorphic materials derived from Cockeysville Marble. The dominant tree species are American beech (Fagus grandifolia), red oak (Quercus rubra), black oak (Quercus velutina), and tulip poplar (Liriodendron tulipifera) $(85,86)$. WCC flows into the Christina River, a tributary of the Delaware. The Neversink River watershed is contained within a mountainous region in northeast New York state with elevations ranging from $480 \mathrm{~m}$ to 1,280 $\mathrm{m}$. The hill slopes are steep with several deeply incised headwater channels, and the soils in the Catskills region are predominantly acidic Inceptisols (87). The glacial till was deposited in the most recent glaciation and generally thicker in stream valleys than along ridge tops. Streambed sediments consist of clay-, silt-, and sand-sized particles and shale-, siltstone-, sandstone-, and conglomerate-derived gravel and cobble in riffles. At the 5th-order site (United States Geological Survey [USGS] station 01435000), mean annual streamflow, stream water temperature, and local precipitation are $5.49 \mathrm{~m}^{3} / \mathrm{s}, 8.3^{\circ} \mathrm{C}$, and $131 \mathrm{~cm}$, respectively. The watershed is sparsely populated and $95 \%$ forested, primarily of mixed northern hardwood species dominated by American beech (Fagus grandifolia), sugar maple (Acer saccharum), and yellow birch (Betula alleghaniensis). Balsam fir (Abies balsamea) is common above 1,000-m elevation, and eastern hemlock (Tsuga canadensis) stands grow in a few areas that have poorly drained soils $(87,88)$. The Neversink River is a tributary of the East Branch Delaware River.

Experimental design. We used a hierarchical design to evaluate spatial patterns of microbial biomass and community structure along a stream order gradient, where stream order refers to the Strahler (89) modification of the Horton (90) classification system. Our nested sampling design (Fig. 1) focused on four spatial scales: (i) between watersheds ( $>350 \mathrm{~km}$ ), (ii) among streams within a watershed $(50 \mathrm{~m}$ to $10 \mathrm{~km}$ ), (iii) among sampling stations within a stream reach ( $2 \mathrm{~m}$ to $25 \mathrm{~m}$ ), and (iv) among cores within a sampling station $(<1 \mathrm{~m})$. In WCC, we sampled one 3rd-order reach adjacent to the Stroud Water Research Center in Avondale, PA (WCC), the two 2nd-order tributaries, White Clay Creek West (WCW) and White Clay Creek East (WCE), and four 1st-order tributaries, two for each 2nd-order stream, Ledyard Spring Brook (LSB) and Water Cress Spring (WCS), which flow into WCW, and Dirty Dog Spring (DDS), and Walton Spring Brook (WSB), which flows into WCE. The forest canopy varied between dense and open along the WSB bank. In Neversink, we sampled the 5th-order Neversink River (NVR), two 3rd-order tributaries of the West Branch Neversink River, Biscuit Brook (BBR) and Pigeon Brook (PBR), and four 1st-order tributaries (Biscuit Brook Tributary A $[B B A]$ and B $[B B B]$ and Pigeon Brook Tributary A $[\mathrm{PBA}]$ and B $[\mathrm{PBB}]$ ). The United States Geological Survey maintains stream gauges at two of the Neversink sites (USGS 01434025, Biscuit Brook $300 \mathrm{~m}$ above the confluence with Pigeon Brook, and USGS 01435000, Neversink River near Claryville). Within each stream, three stations within a reach (downstream, midstream, and upstream) were established, and triplicate sediment cores were collected across each station as independent samples. In summary, the design consisted of 2 stream networks, 7 streams per network, 3 stations per stream, and 3 replicate sediment cores per station, yielding 126 samples. Within the watersheds sampled, both rivers are unregulated. All streams within a watershed were sampled in the same week, and both watersheds were sampled within a 2-week period in July and August 2010 to reduce seasonal differences.

Sampling procedures. Samples were delimited with a 100-mm diameter plastic ring that was inserted $2 \mathrm{~cm}$ deep into the streambed (a 75-mm diameter ring was used for 1st-order streams whenever large rocks, cobbles, or stones dominated the streambed). Plexiglas plates were slipped under and over the ring to effectively trap the sediments and allow them to be lifted intact from the streams with minimal disturbance. Sediments in the top $2 \mathrm{~mm}$ within the ring were transferred with a sterile spatula to prelabeled Whirl-Pak sampling bags and stored on ice before subsampling. Stream water conductivity and water temperature readings were measured with a YSI model 32 conductance meter. Within $6 \mathrm{~h}$ of sampling, sediments were transferred to a clean plastic weigh boat, thoroughly homogenized, subsampled for phospholipids, DNA, surface area, or elemental analyses, and frozen. Frozen samples were shipped to the appropriate laboratory for analysis.

Sediment surface area, particle size, and elemental analyses. Frozen subsamples for surface area and particle size analyses were dried at $60^{\circ} \mathrm{C}$ and split, with one subsample being processed through a US standard sieve series (W. S. Tyler Co., Menton, OH) for sediment particle size distributions. The other subsample was heated to $350^{\circ} \mathrm{C}$ to remove organic matter and analyzed by the Brunauer-Emmett-Teller (three-point adsorption isotherm) method using a Micromeritics Tristar surface area and porosity analyzer (Micromeritics Corporation, Norcross, GA) and $\mathrm{N}_{2}$ as the adsorbate (76).

The frozen subsamples for elemental analysis were freeze-dried and finely ground, and inorganic carbonate was removed (gaseous $\mathrm{HCl}$ ). Approximately $35 \mathrm{mg}$ of sediment was analyzed on a Costech 4010 elemental analyzer for percent carbon and nitrogen and atomic carbon-to-nitrogen ratios (C:N).

Phospholipid analysis. Microbial biomass and community structure were determined using phospholipid phosphate (PLP) and phospholipid fatty acid (PLFA) analyses following the methods of Findlay (45). Briefly, cellular lipids were extracted from the frozen sediment samples transferred directly into dichloromethane/methanol/water and partitioned into aqueous and organic fractions. The organic fraction containing the lipids was subsampled for PLP analysis (91). PLFAs were recovered from other lipids by differential elution from silicic acid columns (J. T. Baker, Center Valley, PA, USA) and were analyzed as their methyl esters. Purified fatty acid methyl esters (FAME) were identified and quantified using gas chromatography. The FAME were analyzed by gas chromatography in an Agilent gas chromatograph equipped with an automatic sampler, a $60 \mathrm{~m} \times 0.25 \mathrm{~mm}$ nonpolar DB-1 column, and a flame ionization detector. Hydrogen was used as the carrier gas at a flow rate of $2.3 \mathrm{~mL} / \mathrm{min}$. The oven temperature was $80^{\circ} \mathrm{C}$ at injection, increased at $4^{\circ} \mathrm{C} / \mathrm{min}$ to $250^{\circ} \mathrm{C}$, and held at $250^{\circ} \mathrm{C}$ for $10 \mathrm{~min}$. FAME identification was based on relative retention times, coelution with standards, and mass spectral analysis. The FAME nomenclature used followed Findlay and Dobbs (92). Using polyenoic fatty acids as indicators of microeukaryotes, total microbial biomass was partitioned between prokaryotic and microeukaryotic organisms, and the results were presented as percentages (92). 
Bacterial community structure analyses by PCR-DGGE. Genomic DNA was extracted from 0.3-g subsamples of the frozen subsamples using the Power Soil DNA extraction kit (MoBio Laboratories, Carlsbad, CA, USA) following the instructions from the manufacturer. DNA was quantified by spectrophotometric absorption at $260 \mathrm{~nm}$, and the purity was assessed from absorbance ratios at 260/280 and 260/230 nm using a ND-2000 Nanodrop spectrometer (Thermo Scientific, Wilmington, DE). 16S rRNA genes were amplified with 1070 (ATGGCTGTCGTCAGCT) and GC-clamped 1392r (ACGGGCGGTGTGTAC) primers (58). The PCRs were performed using an automated Eppendorf Mastercycler thermal cycler (PerkinElmer, Norwalk, CT). PCR-DGGE was performed using the Dcode system (Universal Mutation Detection System, Bio-Rad) as previously described $(58,59)$. Briefly, equal amounts of PCR products were loaded onto an $8 \%$ vertical polyacrylamide gel containing a 50 to $70 \%$ denaturing gradient made of urea and formamide. Gels were electrophoresed at $60^{\circ} \mathrm{C}$ and $70 \mathrm{~V}$ for $16 \mathrm{~h}$ and visualized with SYBR Gold staining (Life Technologies, NY). Digital photographs of gel images were analyzed using GelComparll v.5.10 (Applied Maths, Austin, TX, USA) and visually checked for accuracy. Distinguishable bands represented distinct bacterial taxa that occurred in each sample $(58,59)$, and these data were used for community structure and downstream multivariate statistical analyses.

Statistical analyses. Nested analysis of variance (stations nested within streams and streams within watersheds) with Turkey's honestly significant difference (HSD) test $(P<0.05)$ was performed on sediment organic content and microbial biomass to determine significant differences across spatial scales (JMP 10 and Minitab 16). Across streams, sediments varied greatly in their percent water content, violating the assumption necessary for standardizing data to sediment dry weight (66). Hence, we reported biomass and abundance per gram of sediment fresh weight rather than the customary dry weight. It is our experience that sediments within individual studies were confined to a much narrower range of water content such that normalization to sediment dry weight corrected for differences in sample size and far outweighed the risk of error introduction $(36,93)$. Relationships among variables were investigated using linear regression and multiple regression analyses (Minitab 16). We tested data for normality with the Shapiro-Wilk test and homogeneity of variance with the Bartlett test with appropriate transformations applied as needed. For multiple linear regression analysis, predictor variables (environmental variables) were selected using the "best subsets" algorithm in Minitab. This algorithm fits a small fraction of all possible regression models and reports the "best subset." We identified the best model based on several selection criteria, including adjusted $r^{2}$ and Mallows Cp (94). We used path analysis, a specific form of structural equations modeling (SEM), to explore further the direct and indirect influence of environmental variables (as independent variables) on microbial biomass (as dependent variable) using the SAS structural equation modeling subroutines for JMP 10. SEM is a multivariate statistical technique that tests the importance of pathways in hypothesized models and allows for comparison of models to experimental data (95). Standardized regression coefficients between variables were calculated and plotted as path coefficients on path diagrams constructed for microbial biomass. Natural log-transformed (In [weight\% + 1]) PLFA relative abundance data were subjected to principal-component analysis (PCA) to identify patterns of variation in the microbial community structure across spatial scales and stream orders. PCA was performed for the combined data set of Neversink and WCC networks (SPSS 19). PLFA profiles were interpreted using a functional group approach (92). DGGE data were entered as presence or absence of bands, and pairwise comparisons were calculated and bacterial community structures were analyzed by nonmetric multiple dimensional scaling (NMDS) using the MDS procedure in SAS/ STAT software (v 9.3, SAS Institute Inc., Cary, NC). The bacterial community distributions were illustrated in two-dimensional NMDS plots.

\section{SUPPLEMENTAL MATERIAL}

Supplemental material is available online only.

SUPPLEMENTAL FILE 1, PDF file, $0.3 \mathrm{MB}$.

\section{ACKNOWLEDGMENTS}

Sherman Roberts, Michael Gentile, and Laura Zgleszewski (Stroud Water Research Center, Avondale, PA), and Janna Brown (University of Alabama, Tuscaloosa, AL) assisted in sample collection and processing. Christina Staudhammer provided invaluable advice on the application of path analysis; however, the authors take full responsibility for the application and interpretation of all statistical analyses. Funding for this project was provided by the National Science Foundation grants to R.H.F. (DEB-0516235 and DEB1119922), L.A.K. (DEB-0516449), and J.K. and L.A.K. (DEB-1120717, DEB-1052716, and DEB1557063), and Endowment Fund to J.K. and L.A.K. from Stroud Water Research Center.

\section{REFERENCES}

1. Curtis TP, Sloan WT. 2004. Prokaryotic diversity and its limits: microbial community structure in nature and implication for microbial ecology. Curr Opin Microbiol 7:221-226. https://doi.org/10.1016/j.mib.2004.04.010.

2. Tringe SG, von Mering $C$, Kobayashi A, Salamov AA, Chen K, Chang HW, Podar M, Short JM, Mathur EJ, Detter JC, Bork P, Hugenholtz P, Rubin EM. 2005.
Comparative metagenomics of microbial communities. Science 308:554-557. https://doi.org/10.1126/science.1107851

3. Tank JL, Rosi-Marshall EJ, Griffiths NA, Entrekin SA, Stephen ML. 2010. A review of allochthonous organic matter dynamics and metabolism in streams. J North Am Benthol Soc 29:118-146. https://doi.org/10.1899/08-170.1. 
4. Kaplan LA, Newbold JD. 1993. Biogeochemistry of dissolved organic carbon entering streams, p 139-166. In Ford TE (ed), Aquatic microbiology, an ecological approach. Blackwell, Boston, MA.

5. Pusch M, Fiebig D, Brettar I, Eisenmann H, Ellis BK, Kaplan LA, Lock MA, Naegeli MW, Traunspurger W. 1998. The role of micro-organisms in the ecological connectivity of running waters. Freshw Biol 40:453-495. https://doi.org/10.1046/j.1365-2427.1998.00372.x.

6. Fischer H, Pusch M. 2001. Comparison of bacterial production in sediments, epiphyton, and the pelagic zone of a lowland river. Freshw Biol 46: 1335-1348. https://doi.org/10.1046/j.1365-2427.2001.00753.x.

7. Findlay S. 2010. Stream microbial ecology. J North Am Benthol Soc 29: 170-181. https://doi.org/10.1899/09-023.1.

8. Findlay RH, Battin TJ. 2016. The microbial ecology of benthic environments, p. 4.2.1-1-4.2.1-20. In Yates MV, Nakatsu CH, Miller RV, Pillai SD (ed), 4th ed, Manual of environmental microbiology. ASM Press, Washington, DC.

9. Hart DD. 1992. Community organization in streams: the importance of species interactions, physical factors, and chance. Oecologia 91:220-228. https://doi.org/10.1007/BF00317787.

10. Poff NL, Ward JV. 1992. Heterogeneous currents and algal resources mediate in situ foraging activity of a mobile stream grazer. Oikos 65: 465-478. https://doi.org/10.2307/3545564.

11. Hall RO, Meyer JL. 1998. The trophic significance of bacteria in a detritusbased stream food web. Ecology 79:1995-2012. https://doi.org/10.1890/0012 -9658(1998)079[1995:TTSOBI]2.0.CO;2.

12. Thompson RM, Dunne JA, Woodward G. 2012. Freshwater food webs: towards a more fundamental understanding of biodiversity and community dynamics. Freshw Biol 57:1329-1341. https://doi.org/10.1111/j.1365 $-2427.2012 .02808 . x$.

13. Krause S, Le Roux X, Niklaus PA, Van Bodegom PM, Lennon JT, Bertilsson S, Grossart HP, Philippot L, Bodelier PL. 2014. Trait-based approaches for understanding microbial biodiversity and ecosystem functioning. Front Microbiol 5:251.

14. Loreau M, Mouquet N, Holt RD. 2003. Meta-ecosystems: a theoretical framework for a spatial ecosystem ecology. Ecol Lett 6:673-679. https:// doi.org/10.1046/j.1461-0248.2003.00483.x.

15. Battin TJ, Kaplan LA, Findlay S, Hopkinson CS, Marti E, Packman Al, Newbold JD, Sabater F. 2008. Biophysical controls on organic carbon fluxes in fluvial networks. Nat Geosci 1:95-100. https://doi.org/10.1038/ngeo101.

16. Vannote RL, Minshall GW, Cummins KW, Sedell JR, Cushing CE. 1980. The river continuum concept. Can J Fish Aquat Sci 37:130-137. https://doi .org/10.1139/f80-017.

17. Newbold JD, Elwood JW, O'Neill RV, Winkle WV. 1981. Measuring nutrient spiraling in streams. Can J Fish Aquat Sci 38:860-863. https://doi.org/10 1139/f81-114

18. Guckert JB, Antworth CP, Nichols PD, White DC. 1985. Phospholipid, ester-linked fatty acid profiles as reproducible assays for changes in prokaryotic community structure of estuarine sediments. FEMS Microbiol Ecol 31:147-158. https://doi.org/10.1111/j.1574-6968.1985.tb01143.x.

19. Sanger F, Nicklen S, Coulson AR. 1977. DNA sequencing with chain-terminating inhibitors. Proc Natl Acad Sci U S A 74:5463-5467. https://doi.org/ 10.1073/pnas.74.12.5463.

20. Woese CR, Kandler O, Wheelis ML. 1990. Towards a natural system of organisms: proposal for the domains Archaea, Bacteria, and Eucarya. Proc Natl Acad Sci U S A 87:4576-4579. https://doi.org/10.1073/pnas.87.12 .4576 .

21. Poff NL, Allan JD, Bain MB, Karr JR, Prestegaard KL, Richter BD, Sparks RE, Stromberg JC. 1997. The natural flow regime. Bioscience 47:769-784. https:// doi.org/10.2307/1313099.

22. Peterson EE, Ver Hoef JM, Isaak DJ, Falke JA, Fortin $M-J$, Jordan CE, McNyset K, Monestiez P, Ruesch AS, Sengupta A, Som N, Steel EA, Theobald DM, Torgersen CE, Wenger SJ. 2013. Modelling dendritic ecological networks in space: an integrated network perspective. Ecol Lett 16:707-719. https://doi.org/10.1111/ele.12084.

23. Martiny JBH, Bohannan BJM, Brown JH, Colwell RK, Fuhrman JA, Green JL, Horner-Devine MC, Kane M, Krumins JA, Kuske CR, Morin PJ, Naeem S, Ovreås L, Reysenbach A-L, Smith VH, Staley JT. 2006. Microbial biogeography: putting microorganisms on the map. Nat Rev Microbiol 4:102-112. https://doi.org/10.1038/nrmicro1341.

24. Hanson CA, Fuhrman JA, Horner-Devine MC, Martiny JB. 2012. Beyond biogeographic patterns: processes shaping the microbial landscape. Nat Rev Microbiol 10:497-506. https://doi.org/10.1038/nrmicro2795.

25. Martiny JB, Eisen JA, Penn K, Allison SD, Horner-Devine MC. 2011. Drivers of bacterial beta-diversity depend on spatial scale. Proc Natl Acad Sci U S A 108: 7850-7854. https://doi.org/10.1073/pnas.1016308108.
26. Zhang K, Delgado-Baquerizo M, Zhu YG, Chu H. 2020. Space is more important than season when shaping soil microbial communities at a large spatial scale. mSystems 5:e00783-19.

27. Nemergut DR, Schmidt SK, Fukami T, O'Neill SP, Bilinski TM, Stanish LF, Knelman JE, Darcy JL, Lynch RC, Wickey P, Ferrenberg S. 2013. Patterns and processes of microbial community assembly. Microbiol Mol Biol Rev 77:342-356. https://doi.org/10.1128/MMBR.00051-12.

28. Hullar MA, Kaplan LA, Stahl DA. 2006. Recurring seasonal dynamics of microbial communities in stream habitats. Appl Environ Microbiol 72: 713-722. https://doi.org/10.1128/AEM.72.1.713-722.2006.

29. Findlay RH, Yeates C, Hullar MAJ, Stahl DA, Kaplan LA. 2008. Biome-leve biogeography of streambed microbiota. Appl Environ Microbiol 74: 3014-3021. https://doi.org/10.1128/AEM.01809-07.

30. Gao X, Olapade OA, Leff LG. 2005. Comparison of benthic bacterial community composition in nine streams. Aquat Microb Ecol 40:51-60. https:// doi.org/10.3354/ame040051.

31. Battin TJ, Kaplan LA, Newbold JD, Cheng X, Hansen CM. 2003. Effects of current velocity on the nascent architecture of stream microbial biofilms. Appl Environ Microbiol 69:5443-5452. https://doi.org/10.1128/AEM.69.9 .5443-5452.2003

32. Pohlon E, Mätzig C, Marxsen J. 2013. Desiccation affects bacterial community structure and function in temperate stream sediments. Fundam Appl Limnol 182:123-134. https://doi.org/10.1127/1863-9135/2013/0465.

33. Franken RJ, Storey RG, Williams DD. 2001. Biological, chemical and physical characteristics of downwelling and upwelling zones in the hyporheic zone of a north-temperate stream. Hydrobiologia 444:183-195. https:// doi.org/10.1023/A:1017598005228.

34. Sutton SD, Findlay RH. 2003. Sedimentary microbial community dynamics in a regulated stream: East Fork of the Little Miami River, Ohio. Environ Microbiol 5:256-266. https://doi.org/10.1046/j.1462-2920.2003.00396.x.

35. Feris KP, Ramsey PW, Frazar C, Rillig MC, Gannon JE, Holben WE. 2003. Structure and seasonal dynamics of hyporheic zone microbial communities in Free-Stone Rivers of the western United States. Microb Ecol 46:200-215.

36. Mosher JJ, Findlay RH. 2011. Direct and indirect influence of parental bedrock on streambed microbial community structure in forested streams. Appl Environ Microbiol 77:7681-7688. https://doi.org/10.1128/AEM.06029-11.

37. Pradeep Ram AS, Sime- Ngando T. 2014. Distinctive patterns in prokaryotic community composition in response to viral lysis and flagellate grazing in freshwater microcosms. Freshw Biol 59:1945-1955. https://doi.org/10.1111/ fwb. 12398.

38. Langworthy DE, Stapleton RD, Sayler GS, Findlay RH. 1998. Genotypic and phenotypic responses of a riverine microbial community to polycyclic aromatic hydrocarbon contamination. Appl Environ Microbiol 64:3422-3428. https://doi .org/10.1128/AEM.64.9.3422-3428.1998.

39. Smith RJ, Jeffries TC, Adetutu EM, Fairweather PG, Mitchell JG. 2013. Determining the metabolic footprints of hydrocarbon degradation using multivariate analysis. PLoS One 8:e81910. https://doi.org/10.1371/journal .pone.0081910.

40. Mosher JJ, Klein GC, Marshall AG, Findlay RH. 2010. Influence of bedrock geology on dissolved organic matter quality in stream water. Org Geochem 41:1177-1188. https://doi.org/10.1016/j.orggeochem.2010.08.004.

41. Zeglin LH. 2015. Stream microbial diversity in response to environmental changes: review and synthesis of existing research. Front Microbiol 6:454.

42. Findlay $\mathrm{RH}$, Watling L. 1998. Seasonal variation in the structure of a marine benthic microbial community. Microb Ecol 36:23-30. https://doi.org/ $10.1007 /$ s002489900089.

43. Widder S, Besemer K, Singer GA, Ceola S, Bertuzzo E, Quince C, Sloan WT, Rinaldo A, Battin TJ. 2014. Fluvial network organization imprints on microbial co-occurrence networks. Proc Natl Acad Sci U S A 111:12799-12804. https:// doi.org/10.1073/pnas.1411723111.

44. Besemer K, Singer G, Quince C, Bertuzzo E, Sloan W, Battin TJ. 2013. Headwaters are critical reservoirs of microbial diversity for fluvial networks. Proc Biol Sci 280:20131760.

45. Findlay $\mathrm{RH}$. 2004. Determination of microbial community structure using phospholipid fatty acid profiles, p 983-1004. In Kowalchuk GA, de Bruijn FJ, Head IM, Akkermans AD, van Elsas JS (ed), Molecular microbial ecology manual, 2nd ed. Kluwer Academic Publishers, Dordrecht, the Netherlands.

46. Bobbie RJ, White DC. 1980. Characterization of benthic microbial community structure by high-resolution gas-chromatography of fatty-acid methyl-esters. Appl Environ Microbiol 39:1212-1222. https://doi.org/10.1128/aem.39.6.1212 -1222.1980 .

47. Lang I, Hodac L, FriedI T, Feussner I. 2011. Fatty acid profiles and their distribution patterns in microalgae: a comprehensive analysis of more than 2000 
strains from the SAG culture collection. BMC Plant Biol 11:124. https://doi.org/ 10.1186/1471-2229-11-124.

48. Francoeur SN, Biggs B. 2006. Short-term effects of elevated velocity and sediment abrasion on benthic algal communities. Hydrobiologia 561: 59-69. https://doi.org/10.1007/s10750-005-1604-4.

49. Prieto DM, Devesa-Rey R, Rubinos DA, Diaz-Fierros F, Barral MT. 2016. Biofilm formation on river sediments under different light intensities and nutrient inputs: a flume mesocosm study. Environ Eng Sci 33:250-260. https://doi.org/ 10.1089/ees.2015.0427.

50. Fanta SE, Hill WR, Smith TB, Roberts BJ. 2010. Applying the light: nutrient hypothesis to stream periphyton. Freshw Biol 55:931-940. https://doi .org/10.1111/j.1365-2427.2009.02309.x.

51. Mosher JJ, Kaplan LA, Podgorski DC, McKenna AM, Marshall AG. 2015. Longitudinal shifts in dissolved organic matter chemogeography and chemodiversity within headwater streams: a river continuum reprise. Biogeochemistry 124:371-385. https://doi.org/10.1007/s10533-015-0103-6.

52. Bourguet N, Goutx M, Ghiglione JF, Pujo-Pay M, Mevel G, Momzikoff A, Mousseau L, Guigu C, Garcia N, Raimbault P, Pete R, Oriol L, Lefevre D. 2009. Lipid biomarkers and bacterial lipase activities as indicators of organic matter and bacterial dynamics in contrasted regimes at the DYFAMED site, NW Mediterranean. Deep Sea Res Part II Top Stud Oceanogr 56:1454-1469. https://doi.org/10.1016/j.dsr2.2008.11.034.

53. Wagner K, Besemer K, Burns NR, Battin TJ, Bengtsson MM. 2015. Light availability affects stream biofilm bacterial community composition and function, but not diversity. Environ Microbiol 17:5036-5047. https://doi.org/10.1111/ 1462-2920.12913.

54. Rier ST, Shirvinski JM, Kinek KC. 2014. In situ light and phosphorus manipulations reveal potential role of biofilm algae in enhancing enzyme-mediated decomposition of organic matter in streams. Freshw Biol 59:1039-1051. https:// doi.org/10.1111/fwb.12327.

55. Gibbons SM, Jones E, Bearquiver A, Blackwolf F, Roundstone W, Scott N, Hooker J, Madsen R, Coleman ML, Gilbert JA. 2014. Human and environmental impacts on river sediment microbial communities. PLoS One 9: e97435. https://doi.org/10.1371/journal.pone.0097435.

56. Lindström ES, Langenheder S. 2012. Local and regional factors influencing bacterial community assembly. Environ Microbiol Rep 4:1-9. https:// doi.org/10.1111/j.1758-2229.2011.00257.x.

57. Wang J, Shen J, Wu Y, Tu C, Soininen J, Stegen JC, He J, Liu X, Zhang L, Zhang E. 2013. Phylogenetic beta diversity in bacterial assemblages across ecosystems: deterministic versus stochastic processes. ISME J 7: 1310-1321. https://doi.org/10.1038/ismej.2013.30.

58. Kan J, Wang K, Chen F. 2006. Temporal variation and detection limit of an estuarine bacterioplankton community analyzed by denaturing gradient gel electrophoresis (DGGE). Aquat Microb Ecol 42:7-18. https://doi.org/10 .3354/ame042007.

59. Muyzer G, De Waal EC, Uitterlinden AG. 1993. Profiling of complex microbial populations by denaturing gradient gel-electrophoresis analysis of polymerase chain reaction-amplified genes coding for 16S ribosomal RNA. Appl Environ Microbiol 59:695-700. https://doi.org/10.1128/aem.59.3.695-700.1993.

60. Kan J, Crump BS, Wang K, Chen F. 2006b. Bacterioplankton community in Chesapeake Bay: predictable or random assemblages. Limnol Oceanogr 51:2157-2169. https://doi.org/10.4319/lo.2006.51.5.2157.

61. Wang H, Zhang C, Chen F, Kan J. 2020. Spatial and temporal variations of bacterioplankton in the Chesapeake Bay: a re-examination with highthroughput sequencing analysis. Limnol Oceanogr 65:3032-3045. https:// doi.org/10.1002/Ino.11572.

62. Battin TJ, Besemer K, Bengtsson MM, Romani AM, Packmann Al. 2016. The ecology and biogeochemistry of stream biofilms. Nat Rev Microbiol 14: 251-263. https://doi.org/10.1038/nrmicro.2016.15.

63. Pringle CM, Naiman RJ, Bretschko G, Karr JR, Oswood MW, Webster JR, Welcomme RL, Winterbourn MJ. 1988. Patch dynamics in lotic systems-the stream as a mosaic. J North Am Benthol Soc 7:503-524. https://doi.org/10 $.2307 / 1467303$.

64. Hedges J. 1992. Global biogeochemical cycles: progress and problems. Mar Chem 39:67-93. https://doi.org/10.1016/0304-4203(92)90096-S.

65. Wang YP, Houlton BZ, Field CB. 2007. A model of biogeochemical cycles of carbon, nitrogen, and phosphorus including symbiotic nitrogen fixation and phosphatase production. Global Biogeochem Cycles 21. https:// doi.org/10.1029/2006GB002797.

66. Schallenberg M, Kalff J. 1993. The ecology of sediment bacteria in lakes and comparisons with other aquatic ecosystems. Ecology 74:919-934. https://doi.org/10.2307/1940816.

67. Steenwerth KL, Jackson LE, Calderón FJ, Stromberg MR, Scow KM. 2002. Soil microbial community composition and land use history in cultivated and grassland ecosystems of coastal California. Soil Biol Biochem 34: 1599-1611. https://doi.org/10.1016/S0038-0717(02)00144-X.

68. Fierer N, Morse J, Berthrong S, Bernhardt ES, Jackson RB. 2007. Environmental controls on the landscape-scale biogeography of stream bacterial communities. Ecology 88:2162-2173. https://doi.org/10.1890/06-1746.1.

69. Nemergut DR, Cleveland CC, Wieder WR, Washenberger CL, Townsend AR. 2010. Plot-scale manipulations of organic matter inputs to soils correlate with shifts in microbial community composition in a lowland tropical rain forest. Soil Biol Biochem 42:2153-2160. https://doi.org/10.1016/j soilbio.2010.08.011.

70. Findlay S, Tank J, Dye S, Valett HM, Mulholland PJ, McDowell WH Johnson SL, Hamilton SK, Edmonds J, Dodds WK, Bowden WB. 2002. A cross-system comparison of bacterial and fungal biomass in detritus pools of headwater streams. Microb Ecol 43:55-66. https://doi.org/10 .1007/s00248-001-1020-x.

71. Yoshimura C, Gessner MO, Tockner K, Furumai H. 2008. Chemical properties, microbial respiration, and decomposition of coarse and fine particulate organic matter. J North Am Benthol Soc 27:664-673. https://doi.org/ 10.1899/07-106.1.

72. Hedin L. 1990. Factors controlling sediment community respiration in woodland stream ecosystems. Oikos 57:94-105. https://doi.org/10.2307/3565742.

73. Treves DS, Xia B, Zhou J, Tiedje JM. 2003. A two-species test of the hypothesis that spatial isolation influences microbial diversity in soil. Microb Ecol 45:20-28. https://doi.org/10.1007/s00248-002-1044-x.

74. Nogaro G, Datry T, Mermillod- Blondin F, Descloux S, Montuelle B. 2010. Influence of streambed sediment clogging on microbial processes in the hyporheic zone. Freshw Biol 55:1288-1302. https://doi.org/10.1111/j.1365-2427 2009.02352.x.

75. Nogaro G, Datry T, Mermillod- Blondin F, Foulquier A, Montuelle B. 2013. Influence of hyporheic zone characteristics on the structure and activity of microbial assemblages. Freshw Biol 58:2567-2583. https://doi.org/10 $.1111 /$ fwb.12233.

76. Mayer LM, Rossi PM. 1982. Specific surface areas in coastal sediments: relationships with other textural factors. Mar Geol 45:241-252. https://doi .org/10.1016/0025-3227(82)90112-8.

77. Hargrave BT. 1972. Aerobic decomposition of sediment and detritus as a function of particle surface area and organic content. Limnol Oceanogr 17:583-597. https://doi.org/10.4319/lo.1972.17.4.0583.

78. Fenchel T, Blackburn TH. 1979. Bacteria and mineral cycling. Academic Press, London, UK.

79. Woessner WW. 2000. Stream and fluvial plain groundwater interactions: rescaling hydrogeologic thought. Ground Water 38:423-429. https://doi .org/10.1111/j.1745-6584.2000.tb00228.x.

80. Vervier P, Gibert J, Marmonier P, Dole-Olivier MJ. 1992. A perspective on the permeability of the surface freshwater-groundwater ecotone. J North Am Benthol Soc 11:93-102. https://doi.org/10.2307/1467886.

81. Kaplan LA, Newbold JD. 2000. Surface and subsurface dissolved organic carbon, in streams and ground waters, p 237- 258. In Jones JA, Mulholland PJ (ed), Streams and ground waters. Academic Press, San Diego, CA.

82. Wilcox HS, Wallace JB, Meyer JL, Benstead JP. 2005. Effects of labile carbon addition on a headwater stream food web. Limnol Oceanogr 50: 1300-1312. https://doi.org/10.4319/lo.2005.50.4.1300.

83. Battin TJ, Kaplan LA, Newbold JD, Hansen CME. 2003. Contributions of microbial biofilms to ecosystem processes in stream mesocosms. Nature 426:439-442. https://doi.org/10.1038/nature02152.

84. Lewe N, Hermans S, Lear G, Kelly LT, Thomson-Laing G, Weisbrod B, Wood SA, Keyzers RA, Deslippe JR. 2021. Phospholipid fatty acid (PLFA) analysis as a tool to estimate absolute abundances from compositional 16S rRNA bacterial metabarcoding data. J Microbiol Methods 188:106271. https:// doi.org/10.1016/j.mimet.2021.106271.

85. Newbold JD, Bott TL, Kaplan LA, Sweeney BW, Vannote RL. 1997. Organic matter dynamics in White Clay Creek, Pennsylvania, USA. J North Am Benthol Soc 16:46-50. https://doi.org/10.2307/1468231.

86. Wiegner TN, Kaplan LA, Newbold JD, Ostrom PH. 2005. Contribution of dissolved organic $C$ to stream metabolism: a mesocosm study using $13 \mathrm{C}$ enriched tree-tissue leachate. J North Am Benthol Soc 24:48-67. https:// doi.org/10.1899/0887-3593(2005)024<0048:CODOCT>2.0.CO;2.

87. Lawrence GB, Burns DA, Baldigo BP, Murdoch PS, Lovett GM. 2001. Controls of stream chemistry and fish populations in the Neversink Watershed, Catskill Mountains, New York. USGS Report WRIR 00-4040, Troy, NY.

88. Lovett GM, Weathers KC, Arthur MA. 2002. Control of nitrogen loss from forested watersheds by soil carbon:nitrogen ratio and tree species composition. Ecosystem 5:712-718. https://doi.org/10.1007/s10021-002-0153-1. 
89. Strahler AN. 1957. Quantitative analysis of watershed geomorphology. Eos 38:913-920. https://doi.org/10.1029/TR038i006p00913.

90. Horton RE. 1945. Erosional development of streams and their drainage basins: hydro-physical approach to quantitative morphology. Geol Soc Am Bull 56: 275-370. https://doi.org/10.1130/0016-7606(1945)56[275:EDOSAT]2.0.CO;2

91. Findlay RH, King GM, Watling L.1989. Efficacy of phospholipid analysis in determining microbial biomass in sediments. Appl Environ Microbiol 54: 2888-2893.

92. Findlay RH, Dobbs FC. 1993. Quantitative description of microbial communities using lipid analysis, p 271-284. In Kemp PF, Sherr BF, Sherr EB, Cole JJ (ed), Handbook of methods in aquatic microbial ecology, 1st ed. CRC Press, Boca Raton, FL.

93. Smoot JC, Findlay RH. 2001. Spatial and seasonal variation in a reservoir sedimentary microbial community as determined by phospholipid analysis. Microb Ecol 42:350-358.

94. Mallows CL. 1973. Some comments on Cp. Technometrics 15:661-675. https://doi.org/10.2307/1267380.

95. Mitchell RJ. 1992. Testing evolutionary and ecological hypotheses using path analysis and structural equation modeling. Funct Ecol 6:123-129. 